Published as:

Conway, D., Nicholls, R.J., Brown, S., Tebboth, M.G., Adger, W.N., Ahmad, B., Biemans, H., Crick, F., Lutz, A.F., De Campos, R.S., Said, M., Singh, C., Zaroug, M. A. H., Ludi, E., New M. and Wester, P. 2019. The need for bottom-up assessments of climate risks and adaptation in climate-sensitive regions. Nature Climate Change 9, 503-511.

\title{
The need for bottom-up assessments of climate risks and adaptation in climate-sensitive regions
}

Declan Conway ${ }^{1 *}$, Robert J. Nicholls ${ }^{2}$, Sally Brown ${ }^{2,3}$, Mark Tebboth ${ }^{4,5}$, William Neil Adger $^{6}$, Bashir Ahmad ${ }^{7}$, Hester Biemans ${ }^{8}$, Florence Crick ${ }^{1,9}$, Arthur F. Lutz ${ }^{10,11}$, Ricardo Safra De Campos ${ }^{6}$, Mohammed Said ${ }^{11}$, Chandni Singh ${ }^{12}$, Modathir Abdalla Hassan Zaroug ${ }^{13}$, Eva Ludi ${ }^{14}$, Mark New ${ }^{13}$ and Philippus Wester ${ }^{15}$.

${ }^{1}$ Grantham Research Institute on Climate Change and the Environment. London School of Economics and Political Science, Houghton Street, London, WC2A 2AE, UK.

${ }^{2}$ School of Engineering, University of Southampton, Southampton. SO17 1BJ, UK.

${ }^{3}$ Department of Life and Environmental Sciences, Faculty of Science and Technology, Bournemouth University, Fern Barrow, Poole, Dorset, BH12 5BB, UK

${ }^{4}$ School of International Development, University of East Anglia, Norwich, NR4 7TJ, UK.

${ }^{5}$ Tyndall Centre for Climate Change Research, University of East Anglia, Norwich, NR4 7TJ, UK.

${ }^{6}$ Geography, College of Life and Environmental Sciences, University of Exeter, EX4 4RJ, Exeter, UK.

${ }^{7}$ Climate, Energy and Water Resources Institute. National Agricultural Research Centre, NIH, Shehzad Town, Park Road, Islamabad, Pakistan.

${ }^{8}$ Wageningen Environmental Research, PO Box 47, Wageningen, The Netherlands.

${ }^{9}$ International Institute for Environment and Development (IIED), 80-86 Gray's Inn Road, London, WC1X 8NH, UK.

${ }^{10}$ FutureWater, Costerweg 1V, 6702 AA Wageningen, The Netherlands.

${ }^{11}$ Department of Physical Geography, Utrecht University, P.O. Box 80.115, Utrecht, The Netherlands.

${ }^{11}$ Kenya Markets Trust, Nairobi, Kenya.

${ }^{12}$ Indian Institute for Human Settlements, Bangalore City Campus 197/36, 2nd Main Road, Sadashivanagar Bangalore 560 080. India.

${ }^{13}$ African Climate \& Development Initiative, 6th floor Geological Sciences Building, University Avenue South, University of Cape Town, Rondebosch, 7700, Cape Town, South Africa.

${ }^{14}$ Overseas Development Institute, 203 Blackfriars Road, London, SE1 8NJ, UK.

${ }^{15}$ International Centre for Integrated Mountain Development, GPO Box 3226, Kathmandu, Nepal.

*Author for correspondence: d.conway@1se.ac.uk 


\begin{abstract}
$\underline{\text { Abstract }}$
Studies of climate change at specific intervals of future warming have primarily been addressed through top-down approaches using climate projections and modelled impacts. In contrast, bottom-up approaches focus on the recent past and present vulnerability. Here, we examine climate signals at different increments of warming and consider the need to reconcile top-down and bottom-up approaches. We synthesise insights from recent studies in three climate-sensitive systems where change is a defining feature of the human-environment system. Whilst top-down and bottom-up approaches generate complementary insights into who and what is at risk, integrating their results is a much needed step towards developing relevant information to address the needs of immediate adaptation decisions.
\end{abstract}

\title{
Introduction
}

It is well established that a global mean level of warming can include large differences in rates of regional warming and the magnitude of impacts between and within countries, even at $1.5^{\circ} \mathrm{C}$ and $2{ }^{\circ} \mathrm{C}^{1-3}$. For example, in the ensemble mean of CMIP5 models the future warming rate over drylands was found to be roughly 1.35 times that of the global mean surface warming ${ }^{4}$. Studies on the emergence of climate change also suggest that in low latitude regions climate signals may emerge more quickly than in many areas of the world ${ }^{5}$. Moreover, impacts are not always linearly related to global mean temperature, for example at $1.5^{\circ} \mathrm{C}$ simulated maize yields in drylands decrease slightly, whereas at $2.0^{\circ} \mathrm{C}$ more significant reductions in yield occur ${ }^{4}$. One estimate based on a range of emissions scenarios shows future daily temperature extremes will affect the poorest $20 \%$ to a greater extent than the wealthiest $20 \%$ of the global population, because of the geographical distribution of poverty ${ }^{5}$, a result confirmed in many studies and assessments ${ }^{6}$

Understanding the impacts of $1.5^{\circ} \mathrm{C}$ of mean warming compared to the impacts at $2{ }^{\circ} \mathrm{C}$, is a major challenge for research and policy, and to date has primarily been addressed through top-down modelling approaches. Top-down assessments involve taking climate model projections as a starting point to assess physical and ecological impacts and using multiple projections to assess ranges of uncertainty for future states. We refer here to this wide body of modelling and assessment activity as the top-down approach ${ }^{7,8}$. Top-down assessments are most frequently applied to define initial assumptions and to scope adaptation assessments, often without critical engagement with underlying physical or social relations within the original models of the systems ${ }^{9}$. Such approaches are not without their challenges and whilst these have been recognized for some time ${ }^{7,10,11}$ progress towards effective linkage between top-down and alternative approaches has been piecemeal ${ }^{12,13}$. 
There are multiple challenges. First, methodological complexities mean that various methods have been used to develop projections from global climate models at different levels of warming each with its own strengths and weaknesses ${ }^{14}$. Some changes will also continue after global climate has been stabilised around a given level, especially sea-level rise which has a strong commitment ${ }^{15,16}$. Second, impact model inter-comparison exercises such as The Inter-Sectoral Impact Model Intercomparison Project (ISIMIP, including biophysical and economic models) have shown that results from different impact models simulating the same systems under the same climate change conditions may show considerable variability ${ }^{17,18}$. Third, describing biophysical impacts of climate change produces a generalized indication of future risks, but in itself this does not provide a direct entry point into present-day decisionmaking and adaptation ${ }^{\text {e.g. } 19-21}$. This additional step involves translation of model results into more user-relevant information that is contextualized to suit the specific needs of agencies, communities and individuals, and generally requires a role for intermediaries ${ }^{22-24}$. A focus on 'systems of receptors rather than conventional sectors' ${ }^{25}$ can be useful; one such example is a multidisciplinary methodology building on value chain mapping, with analysis tailored to the specific characteristics of semi-arid areas (seasonality, mobility and informality) and assessing climatic risks at all stages of the value chain ${ }^{26}$.

The essential and common elements of bottom-up assessments are: finer geographical scale and focus on physical, ecological or social processes and current sensitivity to weather and climate; assessments of the plausible options for adaptation within current technological, ecological or perceived social limits; and a diversity of normative measures of risk to elements of society including strong analytical emphasis on vulnerable populations ${ }^{27,28}$. To our knowledge there are relatively few examples of bottom-up approaches at specific levels of warming ${ }^{\text {e.g. } 29}$, because these holistic studies include multiple drivers of change (which can be significant), and because many bottom-up studies seek to produce contextualised information relevant for decision-makers, whatever levels of climate impacts are plausible ${ }^{7,30}$. Furthermore, a major discrepancy exists between the large scale at which biophysical impacts of climate change are generally studied and the local scale of analysis typically adopted in bottom-up studies ${ }^{31,32}$. The bottom-up approaches are people-centred and attempt to derive and generate knowledge based on peoples' understandings of present and changing conditions, risks and responses. Such studies take a person or population as the starting point and seek to locate climate change within a broader array of vulnerabilities and behaviours ${ }^{19}$. 
Both bottom-up and top-down approaches grapple with the challenge of characterising the effects of climate change in complex human-environment systems. This complexity is strongly manifest in many developing countries where current rates of socio-economic and environmental change are unprecedented. Population growth, urbanization and other nonclimate stressors may obscure the effects of slow onset changes in climate and changes in the frequency/intensity of infrequent extreme events. The direct and indirect impact pathways of climate effects are entangled in webs of interconnections at various temporal and spatial scales $^{\text {e.g. }}{ }^{33}$. It is noteworthy that the IPCC AR5 only attributes a few changes to observed climate change with high confidence of detection and attribution: many observed effects could be explained by mechanisms other than observed climate change ${ }^{34}$. The assumptions required for modelling often preclude the ability to capture such detail. Whilst more bottomup fine-grained analyses address complexity, their results may be difficult to generalize because of their specificity.

Many frameworks have been proposed for adaptation ${ }^{28}$, climate risk management ${ }^{\text {e.g. }}{ }^{35,36}$ or risk screening e.g. 37,38. Most approaches incorporate elements of top-down and bottom-up approaches and involve a sequence of actions and, that can be broadly summarized as follows: (1) consult about the problem and agree the aims of the exercise; (2) integrate climate risks in the context of users' wider attitudes to risk (including non-climate risks) and decision-making processes; (3) identify current vulnerabilities to climate and assess the significance of future climate risks to current situations or plans; (4) identify options and prioritise responses; (5) implement decisions; and (6) monitor, evaluate and adjust.

The assessment of risks (stage (3) in the list above) has been dominated by top-down approaches and is challenging as climate projections and impacts are highly uncertain, even in the near term and frequently do not match user requirements for specific detail and levels of confidence that are sufficient to influence decisions. Resolution of these issues and the dichotomy between bottom-up and top-down approaches has the potential to contribute to the demands of international and national adaptation policy. Policy-driven requirements are creating examples of pragmatic approaches to climate risk assessment ${ }^{25}$, although to date they are primarily in high-income countries and none consider change at specific levels of warming. For example, The Dutch National Climate Change Adaptation Strategy adopted a rationalised approach to climate model projections using just four combinations comprising moderate and warm global temperature increases coupled with low and high atmospheric circulation pattern changes ${ }^{39}$; The Third US National Climate Change Assessment 
emphasised recent climate trends and vulnerabilities within regions and sectors to characterise future risks and opportunities ${ }^{40}$; The UK Second Climate Change Risk Assessment adopted a stronger focus on present day and future vulnerability, and prioritisation of adaptation action ${ }^{25}$.

The synthesis of top-down and bottom-up approaches presented here draws on experiences and examples from the Collaborative Adaptation Research Initiative in Africa and Asia (CARIAA) research programme that aimed to build resilience in three climate sensitive systems by supporting research on adaptation to inform policy and practice ${ }^{41}$. CARIAA comprised four multi-disciplinary consortia with partners from the global north and south, mainly universities but including think-tanks, non-governmental organisations and practitioners. The design and diversity of each consortium and the programme as a whole highlight the range of activities and roles necessary to understand and inform actions on adaptation. The requirement to inform policy and the prior experience of the research teams led the programme to cultivate similar elements to the national assessments described above and to include many examples of top-down and bottom-up approaches.

In this Perspective, we address two questions: to what extent is it possible to characterise climate signals at increments of warming in rapidly changing situations? And is it possible to reconcile results from top-down climate model projections of climate change with bottom-up assessments of vulnerability to inform actions on adaptation? We present insights from both top-down climate projections and bottom-up descriptions based on recent research conducted through CARIAA (see Table 1 for a summary of locations and methods used in the studies presented here). These studies come from three climate sensitive systems (areas with high numbers of vulnerable, poor, or marginalized people intersecting with a strong climate change signal ${ }^{32,42}$ ); deltas, semi-arid lands, and river basins dependent on glaciers and snowmelt. We describe methodologies for the alternative top-down and bottom-up approaches and summarise results from studies based on contrasting methods. We conclude with a discussion of the need to reconcile the different approaches to produce decisionrelevant information for adaptation at specific intervals of global warming.

\section{Climate projections and modelling impacts (top-down)}

Table 2 summarises the main results of Global Climate Model (GCM) projections for each climate sensitive system. With warming at $1.5^{\circ} \mathrm{C}$ and $2.0^{\circ} \mathrm{C}$, deltas still experience slow 
ongoing sea-level rise (even if emissions or temperatures stabilise), compounded by subsidence, and potential impacts increase to 2100 and beyond. The GCM projections show rates of warming higher than the global mean in most cases across 49 African countries/semiarid lands ${ }^{45}$. Higher warming is also seen across the river basins dependent on glaciers and snowmelt of the Indus, Ganges and Brahmaputra. Due to elevation dependent warming, mountains are more susceptible to warming than the global average ${ }^{58}$. A global temperature rise of $1.5^{\circ} \mathrm{C}$ implies a warming of $2.1 \pm 0.1^{\circ} \mathrm{C}$ in the high mountains of Asia ${ }^{59}$. Whilst the studies did not include detailed impacts modelling the levels of warming suggest that adaptation for these regions (which is not specified) would need to consider impacts of warming above $1.5^{\circ} \mathrm{C}$ and $2.0^{\circ} \mathrm{C}$ in both systems.

\section{Dynamics of vulnerability and adaptation options (bottom-up)}

\section{Deltas - observational mixed methods studies}

Adaptation options are diverse in delta environments: these regions are accessible, productive and are frequently sites of major populations and urban economic growth poles ${ }^{60}$. Delta social-ecological systems are functionally diverse, and incorporate regions dependent on fisheries, aquaculture, agriculture and rapidly developing economies. Global assessments of climate risks to deltas as natural systems have principally highlighted biophysical risks from sea level change, subsidence and salinization of coastal waters, exacerbated by dam building and regulation of rivers ${ }^{61}$. To test propositions about adaptation options and vulnerability, integrated assessments of adaptation, vulnerability and mobility were designed as part of the CARIAA programme, using policy analysis and observational studies on individual behaviour and choice using both in depth and extensive methods, building on experience of integrating bottom-up and top-down assessments for delta regions ${ }^{62}$.

Critical adaptation dilemmas in deltas include the balance between hard engineering for protection, living with risks and possibly trying to work with nature, and the potential for eventual submergence/loss of coastal land. Governments seek to reconcile these dilemmas and have, for example, intervened to relocate whole vulnerable settlements from coastal regions ${ }^{63,64}$. Many such planned relocations have been shown in bottom up assessments to create new vulnerabilities and loss of agency for the communities involved ${ }^{65}$.

How delta resources are used are the outcome of myriads of individual decisions: hence a need for observational studies on agency and choice. Rice farming practices in deltas, for 
example, are highly exposed to both periodic floods and to creeping salinization, affecting food security and health outcomes ${ }^{51,52}$. In depth methods including semi-structured interviews and focus groups with farming communities in the Mahanadi delta in India, show that insecure land tenure and uneven access to credit drives the spatial patterns of vulnerability to environmental hazards ${ }^{51}$.

Where populations are vulnerable to climate change, does this lead to higher levels of mobility and out-migration from these marginalised areas? Migration is a well-established means of economic development in deltas, which have been net recipients of population over the past five decades ${ }^{66}$. A major cross-sectional representative survey in four delta regions $\left(n=5450\right.$; Table 1) reported $31 \%$ of households with at least one migrant ${ }^{47}$. Additionally, $40 \%$ of household heads reported an intention to migrate in the future. Are environmental risks part of this movement in deltas? The survey data captured motivations for migration: of 1668 households with out-migrants, $60 \%$ reported that economic opportunities were the principal reason behind migration. Only $0.6 \%$ of respondents cited an environmental factor as the main deciding factor. Ostensibly, there were no or few self-reported environmental migrants in deltas under present conditions.

These bottom-up assessments of migration systems and decision-making have shown, across vulnerable environments globally, that environmental factors are significant in driving migration decisions, even where they are not directly reported as the principal motivation, or the risks are long term in nature ${ }^{67-69}$. In the CARIAA research a large proportion of populations over the four delta areas reported increased degradation, increased exposure to hazards, and declining environmental quality over a five year period. Perceived environmental risks such as erosion, floods and cyclones were found to be positively and significantly correlated with future migration behaviour across all deltas ${ }^{47}$. The diverse studies across deltas indicate that adaptation options are highly limited in socially marginalised populations, and that established migration flows, which have acted as a mechanism for diversifying risk, are sensitive to climate changes.

\section{Semi-arid lands - life histories}

Livelihoods in semi-arid lands are under pressure due to macro-economic changes and incorporation into global markets, national development priorities, increasingly variable and stressed environmental conditions, and social and cultural change ${ }^{53}$. The interaction of 
macro-level changes with highly dynamic local conditions generates a constant flux in livelihoods as people respond to changes and seek to actively manage their vulnerability ${ }^{70-72}$. A life history approach was adopted by the CARIAA programme to understand the trajectories of people's lives ${ }^{73-76}$ that builds on approaches in the area of livelihood responses but has rarely been applied to study vulnerability and adaptation in relation to climate change ${ }^{77,78}$ (Table 1). The study examined how livelihoods in semi-arid lands are characterised by 'everyday mobility' (less exceptional than migration and built into the fabric of people's lives) and how this mobility shapes household risk portfolios and adaptation behaviour ${ }^{79}$. A strength of this approach is its capacity to capture significant points in people's lives and emphasise how risk and response portfolios change over time.

Across four semi-arid regions studied in Ghana, Kenya, Namibia and India, the results showed that mobility is an essential feature of many livelihoods (e.g. pastoralism, farming, natural resource-based trading). Mobility enables people to access livelihoods (e.g. commuting) and provides a means to relocate and swap one location for another ${ }^{80}$. Four dominant, but not exclusive, mobility types were identified: high frequency, short duration and often cyclical mobility; more idiosyncratic movement of varying durations and frequencies; permanent relocation; and immobility.

These cases demonstrate the fluid nature of migrant livelihoods across rural and urban areas and showcase how people switch between livelihoods often in opportunistic and unplanned ways. Whilst the risks, such as drought but also things like conflict, gender-based violence, and family deaths, are strongly associated with specific livelihoods they also hint at the more structural nature of vulnerability. For example, chronic conflict that erupts periodically and is simply unavoidable for many undermines the already marginal livelihoods practiced. Moving is often found to bring new risks as well as helping to positively impact on the profile of existing risks.

A dynamic relationship between livelihood shocks and responses is apparent. The ability to conceptualise a person's trajectory is important as it can reveal whether they are moving in a positive or negative direction ${ }^{53}$. Knowledge about a trajectory and the nature of the risks and adaptation options available to a person or household can provide a good indication of the type of interventions that might be effective $e^{78,79,81}$ and when to intervene.

\section{Semi-arid lands - survey and econometrics}


Econometric techniques can be used to tease out specific relationships between climate factors and wider socio-economic activities to study how adaptation is manifest and its major influences, based on empirical data obtained through one-off or repeat surveys. The object of analysis is generally economic agents, often farmers ${ }^{82,83}$, but includes small businesses ${ }^{84}$ that represent a critical employment opportunity for many people, in particular in rural areas in developing countries ${ }^{85}$. Analytical scales may range from studies of individuals using qualitative ${ }^{86}$ and quantitative methods ${ }^{87}$ to studies of large organisations ${ }^{88}$.

Within the CARIAA programme a survey of Small and Medium Enterprises (SMEs) in Kenya and Senegal was designed to collect extensive information on firms' adaptation behaviour to both current climate variability and future climate change ${ }^{52}$ (Table 1). Adaptation responses were grouped into three categories: sustainable adaptation (business preservation measures); unsustainable adaptation (business contraction measures, including sale of assets); and planning measures firms take to prepare for climate change (forward looking and long term). Statistical models were used to examine two questions: how the balance between sustainable and unsustainable adaptation changed as a function of climate stress; and how current adaptation behaviour affected the likelihood of firms planning for future climate change. Surveyed firms reported on their exposure to droughts, floods and various other extreme climate events.

The average number of climate extremes experienced by firms in the last five years was 1.86 $(\mathrm{SD}=1.49)$. Of those surveyed, two thirds did not recognize climate change as an immediate priority. Nevertheless, the survey results revealed that the majority of firms (52\%) are adapting to current climate variability and employing a range of strategies, often including a mixture of sustainable and unsustainable measures. Adapting firms experienced substantially higher climate risks but only $45.2 \%$ of firms had adopted some sustainable adaptation measures, whilst $25.6 \%$ resorted to business contraction strategies. The most frequent adaptation response was an adjustment in the commodities or crops produced.

Using an ordered probit model, the link between current adaptation behaviour and the likelihood of planning for future climate change was examined ${ }^{43}$. The extent and quality of current adaptation practices was found to have a significant influence on the probability that SMEs would plan for future climate change. SMEs which were currently engaging in adaptation practices were more likely to plan for future climate change and the likelihood of future planning was higher for those adopting sustainable practices. The authors note that 
their analysis was based on cross-sectional evidence making it difficult to determine conclusively the causality of some of the correlations obtained - collection of panel data would strengthen the evidence base ${ }^{52}$.

\section{Glacier and snowmelt dependent river basins - mixed methods}

There is an important strand of bottom-up approaches represented in community-based adaptation $^{89}$ and community-level risk assessments ${ }^{90}$ that draw from an underlying positionality that aims to foster participatory engagement through a suite of methods that comprise participatory rural appraisal ${ }^{91}$. These methods are designed to elicit information about livelihood contexts, resilience and local hazards through dialogues, seeking to gain trust of communities. Through learning about the indigenous capacities, knowledge and practices, the aim is to identify local risks and responses ${ }^{89}$.

As part of CARIAA, in the Gandaki river basin in Nepal household surveys that considered migration decisions, major environmental stressors and adaptations ${ }^{54}$ were complemented by consultations including focus group discussions with village development committees, and interviews with stakeholders at local, district and national levels to identify, categorize and rank feasible adaptation options ${ }^{55}$. A majority of the households (91\%) reported perceiving changes in the climate and experiencing environmental shocks over the last decade including increase in annual, summer and winter average temperature. Households also reported a decrease in rainfall and snowfall and more erratic rainfall. Agriculture is the major source of livelihood for more than $80 \%$ of the households, but only $35 \%$ of the households reported at least one adaptation measure, despite more than $90 \%$ perceiving a change in the climate. The response measures undertaken by households are mostly autonomous and taken to ward off immediate risks rather than proactive adaptive strategies.

In upstream areas of the basin, education was the major reason given for migration followed by employment, whereas in midstream and downstream areas, seeking employment was the major driver. Only three per cent of respondents had been displaced temporarily due to extreme events in the last ten years. Permanent outmigration of whole families was high and this large-scale depopulation was felt to have negatively impacted existing socioecological systems, increased human-wildlife conflict and increased invasive species, with negative consequences in the agricultural sector. The overall impact of these changes is contributing to the neglect or abandonment of agricultural lands in these study sites ${ }^{92}$. 


\section{Discussion}

We set out to consider the extent to which it is possible to characterise climate signals in rapidly changing developing country situations and at particular increments of warming. The top-down climate model projections suggest that rates of warming in climate sensitive systems are likely to be higher than the global mean and that there are quantifiable differences in temperature and, to a lesser extent precipitation, between $1.5^{\circ} \mathrm{C}$ and $2.0^{\circ} \mathrm{C}$. We note that the methodological challenges associated with defining changes in GCM projections have not been dealt with consistently across the studies and this might affect the magnitude of some of the differences obtained. Whilst this is an important point from a scientific perspective, the level of technical complexity required to achieve full consistency would likely be too demanding for the operational realities of adaptation planning. For deltas the slow response in sea level rise has consequences beyond 2100 even with a stable temperature ${ }^{16}$. Hence stabilisation of climate reduces the threats to deltas, but it is insufficient to characterise these benefits solely by analysing reduced flood depths and areas in this century. Similarly, even if global temperature stabilized at its present level, Asian glaciers would continue to lose mass through the entire 21 st century ${ }^{59}$.

The top-down studies we consider here do not simulate the sectoral impacts of climate model projections - the impacts are implied - and presented with the message that in many cases they will be greater in these climate sensitive systems than the global mean. Such information is valuable to a mitigation agenda aiming to cut emissions to reduce long-term future impacts $^{113}$. It might be desirable to run sectoral or integrated assessment models with these projections to describe impacts. However, impact models have their own limitations including inter-model differences and high demands for data inputs and technical capacity, often lacking in low income countries. These issues compound the challenge of incorporating and communicating the high levels of uncertainty arising from multiple climate projections, particularly for precipitation (e.g. the projections for African countries/semi-arid lands in West Africa in Table 2 include both wetting and drying scenarios).

In all four bottom-up examples socio-economic change is, if not a defining then at least highly important, feature of the human-environment system. However, the extent to which 
socio-economic change dominates the climate narrative is partly a function of the aims and scope of the analysis. Where there is a strong aim to focus purely on the role of climate, it inevitably forms a large part of the results. For example, analysis in Nepal (in one of the glacier and snowmelt dependent basins) shows strong linkages between the effects of climate trends and extremes on livelihood outcomes (including migration). In cases where the aims are more targeted to understanding system dynamics (such as in the life histories approach in semi-arid regions), a more complex picture emerges in which the role of climate is hard to disentangle, or features as a minor direct influence on the process being studied. In deltas the rates of socio-economic change are so high in recent and near-term future decades (for example, in the last 70 years, Bangladesh's population increased more than four times) that they all but swamp climate signals ${ }^{60-62}$, apart from short-run effects of extreme events like cyclones. In semi-arid lands variability and flux are clearly inherent and critical aspects of the human-environment system; it is therefore essential to consider both climate and non-climate factors for a full understanding of such systems relevant to effective adaptation and development even within the timescales of when $1.5^{\circ} \mathrm{C}$ and $2.0^{\circ} \mathrm{C}$ warming could occur.

The bottom-up approaches consider the effects of climate change in the recent past, typically based on recall, and on specific aspects of human-environment systems. The surveys and statistical modelling exercises presented here test hypotheses about the role of climate hazards in affecting migration decisions and SME actions on adaptation. The life histories and participatory survey provide insights to the frequency of mobility associated with changing environmental conditions and the livelihood impacts of climate trends and hazards, respectively. These methods add to the existing suite of approaches such as agent-based modelling, climate analogues and participatory scenario planning that examine climatic and non-climatic drivers of adaptation action ${ }^{78}$. Climate signals in all four examples are manifest in complex ways within each system and beyond damage assessments of specific extreme events, it is extremely challenging to characterise in detail the role of climate variability/change. Respondents in the surveys rank environmental factors as a very low linear (or direct) influence on decisions about migration in deltas ${ }^{28}$, and climate change to be a low priority for most SMEs in semi-arid lands ${ }^{47}$. However, in both cases respondents may not include indirect effects in their evaluations, and secondary impacts could include disruption to livelihoods and to reliability of service delivery such as water and electricity, through disruption to infrastructure ${ }^{93}$. The literature on migration cautions against simplistic 'driver-response' analyses arguing that decisions to migrate are highly complex and location 
specific $^{79,94}$. The bottom-up research highlights the reliance either directly or indirectly of many people on the natural environment and the significant role of compounding shocks in people's (downward) trajectories. Bottom-up studies may also address why people are differentially vulnerable and why some people adapt while others do not.

In summary, the four bottom-up examples presented here do not provide clear attribution of climate signals at increments of warming because of confounding factors, but they do find that climatic risks mediate response behaviour. Their focus on the recent past provides valuable insights into vulnerabilities within societies that have experienced the local climate manifestation of about $0.65^{\circ} \mathrm{C}$ global warming since 1950 . These insights are empirical evidence of likely sensitivities and opportunities that will arise as climate change is increasingly manifest in the future. The embeddedness and interplay between climate and society (and hence difficulty with attributing causality) underscores the critical need to situate climate adaptation within the context of broader socio-economic, environmental and political processes; something that top-down approaches often fail to consider.

Our second aim was to examine whether it is possible to reconcile results of top-down model simulations of climate impacts with bottom-up analyses of vulnerability, to inform actions on adaptation. A large part of the difference in the resulting knowledge generated is ultimately derived from this contrast in approach: one that embraces the complexity of lived experiences and the other that aims to simplify complex systems to simulate the climate signal. Bottomup approaches comprise a vast array of initial assumptions, methods, scales and analytical designs. Likewise, top-down approaches have to choose from many different models and assumptions, scales and analytical designs. All methods have their strengths and weaknesses, for example three of the four bottom-up studies have used questionnaire surveys that can be biased in favour of the respondent (particularly the head of household) or lack flexibility to elicit nuances in responses with respect to environmental change and degradation ${ }^{95}$. There are important methodological concerns and more fundamental critiques of the discourse of participation $^{96,97}$.

The multiplicity of choice is not necessarily a bad thing, but providing clear guidance on strengths and weaknesses of methods will help researchers and practitioners with less experience. Moreover, as programmes such as ISIMIP ${ }^{17}$ support standardised approaches to promote consistency and comparability in impacts studies, so bottom-up approaches will need to consider consistency and representativeness. Whilst some bottom-up approaches are not easily commensurate with or appropriate for such requirements ${ }^{98}$, the demand for studies 
of specific intervals of warming (e.g. to inform the IPCC) and the requirement of international programmes to measure and track progress on adaptation ${ }^{99}$ (e.g. Article 7 in the Paris Agreement) will prompt renewed efforts to achieve this. Calls to systematise evidence and findings from the rapidly growing literature on adaptation ${ }^{100,101}$ recognise the importance of this need. Bottom-up studies of adaptation are important for policy development governments are looking for examples of what works and what doesn't work when developing adaptation policies and thus corroborating studies. At the same time such policies are developed within a broader climate change framework often informed by model projections - most if not all National Adaptation Plans and Climate Change Acts will mention or frame policies within a context of future climate projections.

Whilst the examples shown here from the CARIAA programme do not reconcile the alternative approaches (e.g. their timescales and types of information), we argue that it is possible to blend insights from bottom-up and top-down approaches using expert judgement to generate a description of vulnerability and risks that is sufficiently detailed to inform decisions. The four bottom-up cases all provide contextualised insights to climate impacts that can capture the complex exposure units of interest to stakeholders and decision-makers (e.g. factors influencing mobility and business decisions). Although there is a different temporal focus between top-down (future) and bottom-up approaches (past and present) the distinction is not exclusive. Bottom-up knowledge of complex human-environment dynamics has informed agent-based modelling for simulations of the future ${ }^{102,103}$ and the role of climate therein can be used to infer consequences of future climate change impacts at different levels of warming derived from top-down approaches. Top-down approaches can be designed to focus more on recent and current trends, for example, the use of empirical crop-climate relationships and GCM projections to assess near-term food security risks ${ }^{104}$. They can also be designed to address more practical and policy-oriented questions (considering systems of receptors) and to include a wider range of socio-economic and other changes alongside climate. Alternatives to projections involving narrative-based descriptions of climate are also gaining traction ${ }^{105-107}$. In the absence of local and national impacts assessments at specific global warming increments one CARIAA consortium used a hybrid approach to generate locally relevant impacts information ${ }^{108}$. Previous national and regional impact assessments using transient GCM projections were used to identify relevant impacts in water resources, agriculture and health at specific time slices in the future; these results were then scaled by the global temperature in the underlying GCMs to estimate impacts at $1.5^{\circ} \mathrm{C}$ and $2.0^{\circ} \mathrm{C}$. 
Much needed progress in this direction will require increasing engagement between the two broad approaches e.g. $25,39,40,109$. For example, the need for an iterative process that uses the outputs from top-down approaches to feed into the bottom-up approaches, the outputs of which can then be used to increase the skill of top-down approaches. In this way we see a continual process through which both top-down and bottom-up approaches inform each other conceptually and practically, generating hybrid methods and information that is likely to be of greater utility in the short and long-term. A role for knowledge brokers is central to this process as it relies on knowledge synthesis and communication to inform practical actions. This role is already well recognised ${ }^{23,24,110}$. Information from research needs to be filtered to fit knowledge demands of diverse stakeholders, a role or skillset that researchers often lack. In CARIAA for example, each consortium adopted a strongly stakeholder-oriented approach in their research processes, including examples of co-design or repeat consultation through mechanisms like multi-stakeholder platforms, participatory vulnerability and risk assessments $^{111}$, transformative scenario planning ${ }^{112}$, engagement through participatory research and transformative action research with migrants to delta cities ${ }^{47}$. By recognising the fact that throughout any decision-process subjective prioritisation and normative judgements are required ${ }^{28,113}$, no matter how much the process is quantified, an integrated approach based on expert judgement and consultation provides a pragmatic basis for decision-making.

Human-environment systems have co-evolved with climate and by necessity untangling them will always be challenging and will inevitably require blending of methodological approaches. We have presented examples that show the importance of understanding climate within the context of rapidly changing climate sensitive systems in the developing world through bottom-up approaches. Insights from such approaches provide critical information that addresses the needs of practical adaptation agendas. Bottom-up approaches need to receive more recognition in climate risk assessments, including those aiming to characterise impacts at different levels of global warming.

\section{Author contributions}

DC and RJN conceived the paper and outlined the first draft, DC led subsequent drafts, SB, MT, BA, CS, RDC, WNA, FC, AL and MZ contributed case study examples, all authors commented on subsequent drafts and revisions. 


\section{Data availability statement}

No datasets were generated or new analysis performed during the current study.

\section{Acknowledements}

This work is associated to the Collaborative Adaptation Research Initiative in Africa and Asia (CARIAA) with financial support from the UK Government's Department for International Development and the International Development Research Centre, Ottawa, Canada. The views expressed in this work are those of the creators and do not necessarily represent those of the UK Government's Department for International Development, the International Development Research Centre, Canada or its Board of Governors. DC and FC acknowledge financial support from the Grantham Foundation for the Protection of the Environment, and the UK Economic and Social Research Council (ESRC) through the Centre for Climate Change Economics and Policy. WNA and RDC acknowledge financial support from the UK Economic and Social Research Council through grant No ES/R002371/1.

\section{References}

1. Seneviratne, S.I., Donat, M.G., Pitman, A.J., Knutti, R. \& Wilby, R.L. Allowable CO 2 emissions based on regional and impact-related climate targets. Nature 529(7587), 477 (2016).

2. IPCC: Summary for Policymakers. In: Global Warming of $1.5^{\circ} \mathrm{C}$. An IPCC Special Report on the impacts of global warming of $1.5^{\circ} \mathrm{C}$ above pre-industrial levels and related global greenhouse gas emission pathways, in the context of strengthening the global response to the threat of climate change, sustainable development, and efforts to eradicate poverty. Masson-Delmotte, V., P. Zhai, H.-O. Pörtner, D. Roberts, J. Skea, P.R. Shukla, A. Pirani, Moufouma-Okia, C. Péan, R. Pidcock, S. Connors, J.B.R. Matthews, Y. Chen, X. Zhou, M.I. Gomis, E. Lonnoy, Maycock, M. Tignor, and T. Waterfield (eds.). World Meteorological Organization, Geneva, Switzerland, 32 pp, 2018.

3. Schellnhuber, H. J., Hare, B., Serdeczny, O., Schaeffer, M., Adams, S., Baarsch, F., ... \& Piontek, F. Turn down the heat: climate extremes, regional impacts, and the case for resilience. Washington, World Bank, 2013.

4. Huang, J., Yu, H., Guan, X., Wang, G. \& Guo, R. Accelerated dryland expansion under climate change. Nature Climate Change 6, 166-171. (2016).

5. Harrington, L. J., Frame, D. J., Fischer, E. M., Hawkins, E., Joshi, M., \& Jones, C. D. Poorest countries experience earlier anthropogenic emergence of daily temperature extremes. Environmental Research Letters 11(5), 055007 (2016). 
6. Bathiany, S., Dakos, V., Scheffer, M. and Lenton, T.M. Climate models predict increasing temperature variability in poor countries. Science advances 4(5), p.eaar5809 (2018).

7. Dessai, S. \& Hulme, M. Does climate adaptation policy need probabilities? Climate policy 4(2), 107-128 (2004).

8. Lempert, R.J. \& Collins, M.T. Managing the risk of uncertain threshold responses: comparison of robust, optimum, and precautionary approaches. Risk Anal. 27(4), 10091026 (2007).

9. Preston, B. L., Mustelin, J., \& Maloney, M. C. Climate adaptation heuristics and the science/policy divide. Mitigation and Adaptation Strategies for Global Change 20(3), 467-497 (2015).

10. Burton, I., Huq, S., Lim, B., Pilifosova, O., \& Schipper, E. L. From impacts assessment to adaptation priorities: the shaping of adaptation policy. Climate policy 2(2-3), 145-159 (2002).

11. Füssel, H. M. Adaptation planning for climate change: concepts, assessment approaches, and key lessons. Sustainability science 2(2), 265-275 (2007).

12. Porter, J. J., Demeritt, D., \& Dessai, S. The right stuff? Informing adaptation to climate change in British local government. Glob. Environ. Chang. 35, 411-422 (2015).

13. Nissen, H., and Conway, D. From Advocacy to action: projecting the health impacts of climate change. PLoS Medicine 15(7): e1002624 (2018).

14. James, R., Washington, R., Schleussner, C-D., Rogelj, J. \& Conway, D. Characterizing half-a-degree difference: a review of methods for identifying regional climate responses to global warming targets. Wiley Interdisciplinary Reviews Climate Change 8:e457 (2017).

15. Church, J. A., Clark, P. U., Cazenave, A., Gregory, J. M., Jevrejeva, S., Levermann, A., et al. Sea level change. In T. F. Stocker, D. Qin, G.-K. Plattner, M. Tignor, S. K. Allen, J. Boschung, et al. (Eds.), Climate Change 2013. The Physical Science Basis. Contribution of Working Group I to the Fifth Assessment Report of the Intergovernmental Panel on Climate Change. Cambridge, England and New York, NY: Cambridge University Press, 2013.

16. Nicholls, R., Brown, S., Goodwin, P., Wahl, T., Lowe, J., Solan, M., Godbold, J.A., Haigh, I.D., Lincke, D., Hinkel, J., Wolff, C., Merkens, J-L. Stabilization of global temperature at $1.5^{\circ} \mathrm{C}$ and $2.0^{\circ} \mathrm{C}$ : Implications for coastal areas. Philosophical Transactions of The Royal Society A 376(2119) (2018).

17. Rosenzweig, C., Elliott, J., Deryng, D., Ruane, A.C., Müller, C., Arneth, A., Boote, K.J., Folberth, C., Glotter, M., Khabarov, N. \& Neumann, K. Assessing agricultural risks of climate change in the 21st century in a global gridded crop model intercomparison. Proceedings of the National Academy of Sciences 111(9), 3268-3273 (2014).

18. Lampe, M., Willenbockel, D., Ahammad, H., Blanc, E., Cai, Y., Calvin, K., .. \& Kyle, P. Why do global long-term scenarios for agriculture differ? An overview of the AgMIP global economic model intercomparison. Agricultural Economics 45(1), 3-20 (2014).

19. Van Aalst, M. K., Cannon, T., \& Burton, I. Community level adaptation to climate change: the potential role of participatory community risk assessment. Glob. Environ. Chang. 18(1), 165-179 (2008).

20. Kiem, A.S. \& Austin, E.K. Disconnect between science and end-users as a barrier to climate change adaptation. Climate research 58(1), 29-41 (2013). 
21. Kirchhoff, C. J., Lemos, M. C., \& Dessai, S. Actionable knowledge for environmental decision making: broadening the usability of climate science. Annual review of environment and resources 38 (2013).

22. Pielke Jr, R. A. The honest broker: making sense of science in policy and politics. Cambridge University Press, 2007.

23. Vogel, C., Moser, S. C., Kasperson, R. E., \& Dabelko, G. D. Linking vulnerability, adaptation, and resilience science to practice: Pathways, players, and partnerships. Glob. Environ. Chang. 17(3-4), 349-364 (2007).

24. Dilling, L. \& Lemos, M.C. Creating usable science: Opportunities and constraints for climate knowledge use and their implications for science policy. Glob. Environ. Chang. 21(2), 680-689 (2011).

25. Warren, R. F., Wilby, R. L., Brown, K., Watkiss, P., Betts, R. A., Murphy, J. M., \& Lowe, J. A. Advancing national climate change risk assessment to deliver national adaptation plans. Phil. Trans. R. Soc. A 376(2121), 20170295 (2018).

26. Carabine, E., Simonet, C., et al. Value Chain Analysis for Resilience in Drylands (VCARID): Identification of adaptation options in key sectors. VC-ARID synthesis report. Pathways to Resilience in Semi-Arid Economies (PRISE). London, UK, 2018.

27. Kelly, P.M. and Adger, W.N. Theory and practice in assessing vulnerability to climate change and facilitating adaptation. Climatic change 47(4), 325-352 (2000).

28. Moser, S. C. \& Ekstrom, J. A. A framework to diagnose barriers to climate change adaptation. Proceedings of the national academy of sciences 201007887 (2010).

29. de Coninck, H., Revi, A., Babiker, M., Bertoldi, P., Buckeridge, M., Cartwright, A., ... \& Ley, D. Chapter 4: Strengthening and implementing the global response. In: Global Warming of $1.5^{\circ} \mathrm{C}$ : an IPCC special report on the impacts of global warming of $1.5^{\circ} \mathrm{C}$ above pre-industrial levels and related global greenhouse gas emission pathways, in the context of strengthening the global response to the threat of climate change. Cambridge and New York: Cambridge University Press, (2018).

30. Hinkel, J. \& Bisaro, A. Methodological choices in solution-oriented adaptation research: a diagnostic framework. Reg. Environ. Chang. 16, 7-20 (2016).

31. Duerden, F. Translating climate change impacts at the community level. Arctic 57, 204$212(2004)$.

32. Tucker, J., Daoud, M., Oates, N., Few, R., Conway, D., Mtisi, S. \& Matheson, S. Social vulnerability in three high-poverty climate change hot spots: What does the climate change literature tell us? Reg. Environ. Chang. 1-18 (2014).

33. Few, R. \& Tebboth, M.G. Recognising the dynamics that surround drought impacts. Journal of Arid Environments 157, 113-115 (2018).

34. IPCC Field, C.B. \& Barros, V.R. eds. Climate change 2014: impacts, adaptation, and vulnerability (Vol. 1). Cambridge and New York: Cambridge University Press, 2014.

35. Parry, M., \& Carter, T. Climate impact and adaptation assessment: a guide to the IPCC approach. Earthscan (1998).

36. Willows, R., Reynard, N., Meadowcroft, I. \& Connell, R. Climate adaptation: Risk, uncertainty and decision-making. UKCIP Technical Report. UK Climate Impacts Programme, 2003.

37. Klein, R. J., Eriksen, S. E., Næss, L. O., Hammill, A., Tanner, T. M., Robledo, C., \& O'brien, K. L. Portfolio screening to support the mainstreaming of adaptation to climate change into development assistance. Climatic change 84(1), 23-44 (2007).

38. Hammill, A. \& Tanner, T. Harmonising climate risk management: Adaptation screening and assessment tools for development co-operation (No. 36). OECD Publishing, 2011.

39. NAS (Dutch National Climate Adaptation Strategy). Adapting with ambition, 2016. 
40. Melillo, J.M. Climate change impacts in the United States, highlights: US national climate assessment. Government Printing Office, 2014.

41. CARIAA https://www.cariaa.net/home-0 Accessed 23.02.2019

42. De Souza K., Kituyi E., Harvey B., Leone M., Murali K.S., \& Ford J.D. Vulnerability to climate change in three hot spots in Africa and Asia: key issues for policy-relevant adaptation and resilience-building research. Reg. Environ. Chang. 15, 747-753 (2015).

43. Goodwin, P., Brown, S., Haigh, I. D., Nicholls, R. J., \& Matter, J. M. Adjusting mitigation pathways to stabilize climate at 1.5 and $2.0^{\circ} \mathrm{C}$ rise in global temperatures to year 2300. Earth's Future 6, 601-615 (2018).

44. Brown, S., Nicholls, R.J., Goodwin, P., Haigh, I.D., Lincke, D., Vafeidis, A.T. \& Hinkel, J. Quantifying Land and People Exposed to Sea-Level Rise with No Mitigation and $1.5^{\circ} \mathrm{C}$ and $2.0^{\circ} \mathrm{C}$ Rise in Global Temperatures to Year 2300. Earth's Future 6, 583-600 (2018).

45. Zaroug, M., New, M. \& Lennard, C. Climate change in African countries at 1.5 and 2.0 degrees: variation by geography, aridity and continentality. ASSAR Working Paper 4, 23pp. (2019) www.assar.uct.ac.

46. Lutz, A.F., ter Maat, H.W., Wijngaard, R.R., Biemans, H., Syed, A., Shrestha, A.B., Wester, P. \& Immerzeel, W.W. South Asian river basins in a $1.5^{\circ} \mathrm{C}$ warmer world. Regional Environmental Change 19, 833 (2019).

47. Adger, W. N., Safra de Campos, R., Codjoe, S. N. A., Siddiqui, T., Hazra, S., Adams, H., Mortreux, C., Das S. \& Abu, M. Role of perceived environmental risks and insecurity in migration decisions and intentions. One Earth (in review).

48. Szabo, S., Hossain, M.S., Adger, W.N., Matthews, Z., Ahmed, S., Lázár, A.N. \& Ahmad, S. Soil salinity, household wealth and food insecurity in tropical deltas: evidence from south-west coast of Bangladesh. Sustainability Science 11(3), 411-421 (2016).

49. Johnson, F.A., Hutton, C.W., Hornby, D., Lázár, A.N. \& Mukhopadhyay, A. Is shrimp farming a successful adaptation to salinity intrusion? A geospatial associative analysis of poverty in the populous Ganges-Brahmaputra-Meghna Delta of Bangladesh. Sustainability Science 11(3), 423-439 (2016).

50. Al Nahian, M., Ahmed, A., Lázár, A.N., Hutton, C.W., Salehin, M. \& Streatfield, P.K. Drinking water salinity associated health crisis in coastal Bangladesh. Elem. Sci. Anth. 6(1) (2018).

51. Duncan, J., Tompkins, E., Dash, J. \& Tripathy, B. Resilience to hazards: rice farmers in the Mahanadi Delta, India. Ecology and Society 22(4):3 (2017).

52. Crick F., Eskander, S., Fankhauser, S. \& Diop, M. How do African SMEs respond to climate risks? Evidence from Kenya and Senegal. World Development 108, 157-168 (2018).

53. Tebboth, M. Singh, C. Spear, D. Mensah, A. \& Ansah, P. The role of mobility in changing livelihood trajectories: implications for vulnerability and adaptation in semi-arid regions. Geoforum (in review).

54. Maharjan, A., Hussain, A., Bhadwal, S., Ishaq, S., Saeed, B.A., Sachdeva, I., Ahmad, B., Hassan S.M, T., Tuladhar, S., Ferdous, J. Migration in the lives of environmentally vulnerable populations in four river basins of the Hindu Kush Himalayan Region. HIAWARE Working Paper 20. Kathmandu: HI-AWARE (2018).

55. Regmi, B.R., Shrestha, K., Sapkota, R., Pathak, K. What constitutes successful adaptation measures? Reflections from the national and local contexts of Nepal. HI-AWARE Working Paper 17. Kathmandu: HI-AWARE (2018).

56. Brown, S., Nicholls, R.J., Lázár, A.N., Hornby, D.D., Hill, C., Hazra, S., Addo, K.A., Haque, A., Caesar, J. \& Tompkins, E.L. What are the implications of sea-level rise for a 
$1.5,2$ and $3^{\circ} \mathrm{C}$ rise in global mean temperatures in the Ganges-Brahmaputra-Meghna and other vulnerable deltas? Reg. Environ. Chang. 18, 1829-1842 (2018).

57. Nicholls, R. J., Hutton, C. W., Adger, W. N., Hanson, S. E., Rahman, M. M., \& Salehin, M. (eds) Ecosystem service for well-being in deltas: Integrated assessment for policy analysis. Palgrave (2018).

58. Pepin, N. et al. Elevation-dependent warming in mountain regions of the world. Nature Climate Change 5, 424-430, doi:10.1038/nclimate2563 (2015).

59. Kraaijenbrink, P. D. A., Bierkens, M. F. P., Lutz, A. F., \& Immerzeel, W. W. Impact of a global temperature rise of 1.5 degrees Celsius on Asia's glaciers. Nature 549(7671), 257 260 (2017).

60. Seto, K.C. Exploring the dynamics of migration to mega-delta cities in Asia and Africa: Contemporary drivers and future scenarios. Glob. Environ. Chang. 21, S94-S107 (2011).

61. Tessler, Z.D., Vörösmarty, C.J., Grossberg, M., Gladkova, I., Aizenman, H., Syvitski, J.P.M. and Foufoula-Georgiou, E. Profiling risk and sustainability in coastal deltas of the world. Science 349(6248), 638-643 (2015).

62. Nicholls, R.J., Hutton, C.W., Lázár, A.N., Allan, A., Adger, W.N., Adams, H., Wolf, J., Rahman, M. and Salehin, M. Integrated assessment of social and environmental sustainability dynamics in the Ganges-Brahmaputra-Meghna delta, Bangladesh. Estuarine, Coastal and Shelf Science 183, 370-381 (2016).

63. Rogers, S. and Xue, T. Resettlement and climate change vulnerability: evidence from rural China. Glob. Environ. Chang. 35, 62-69 (2015).

64. Wilmsen, B. and Webber, M. What can we learn from the practice of development-forced displacement and resettlement for organised resettlements in response to climate change?. Geoforum 58, 76-85 (2015).

65. Mortreux, C., de Campos, R.S., Adger, W.N., Ghosh, T., Das, S., Adams, H. and Hazra, S. Political economy of planned relocation: A model of action and inaction in government responses. Glob. Environ. Chang. 50, 123-132 (2018).

66. De Sherbinin, A., Levy, M., Adamo, S., MacManus, K., Yetman, G., Mara, V., Razafindrazay, L., Goodrich, B., Srebotnjak, T., Aichele, C. \& Pistolesi, L. Migration and risk: net migration in marginal ecosystems and hazardous areas. Environmental Research Letters 7(4), 045602 (2012).

67. Dun, O. Migration and displacement triggered by floods in the Mekong Delta. International Migration 49, e200-e223 (2011).

68. Renaud, F.G., Dun, O., Warner, K. and Bogardi, J. A decision framework for environmentally induced migration. International Migration 49, e5-e29 (2011).

69. Koubi, V., Spilker, G., Schaffer, L. and Böhmelt, T. The role of environmental perceptions in migration decision-making: evidence from both migrants and non-migrants in five developing countries. Population and environment 38(2), 134-163 (2016).

70. Sietz, D., Lüdeke, M. K. B. \& Walther, C. Categorisation of typical vulnerability patterns in global drylands. Glob. Environ. Chang. 21, 431-440 (2011).

71. Reid, R., S., Fernández-Giménez, M. E. \& Galvin, K. A. Dynamics and resilience of rangelands and pastoral peoples around the Ggobe. Annual Review of Environment and Resources 39, 217-242 (2014).

72. Shackleton, S., Ziervogel, G., Sallu, S., Gill, T. \& Tschakert, P. Why Is Socially-Just Climate Change Adaptation in Sub-Saharan Africa So Challenging? A Review of Barriers Identified from Empirical Cases. Wiley Interdisciplinary Reviews-Climate Change 6, 321344 (2015).

73. Porter, G., Hampshire, K., Mashiri, M., Dube, S. \& Maponya, G. 'Youthscapes' and Escapes in Rural Africa: Education, Mobility and Livelihood Trajectories for Young 
People in Eastern Cape, South Africa. Journal of International Development 22, 10901101 (2010).

74. Langevang, T. 'We Are Managing!' Uncertain Paths to Respectable Adulthoods in Accra, Ghana. Geoforum 39, 2039-2047 (2008).

75. Ansell, N., Hajdu, F., Blerk, L. \& Robson, E. Reconceptualising Temporality in Young Lives: Exploring Young People's Current and Future Livelihoods in Aids-Affected Southern Africa. Transactions of the Institute of British Geographers 39, 387-401 (2014).

76. Singh, C. Using life histories to understand temporal vulnerability to climate change in highly dynamic contexts. SAGE Research Methods Case (2018). DOI: $10.4135 / 9781526440358$

77. Singh, C. Tebboth, M. Spear, D. Ansah, P. \& Mensah, A. Opening up the methodological toolkit on climate change vulnerability and adaptation research: reflections from using life history approaches. Reg. Environ. Chang. (in review).

78. Ford, J. D., Keskitalo, E. C. H., Smith, T., Pearce, T., Berrang-Ford, L., Duerden, F. \& Smit, B. Case Study and Analogue Methodologies in Climate Change Vulnerability Research. Wiley Interdisciplinary Reviews: Climate Change 1, 374-392 (2010).

79. Ayeb-Karlsson, S., Van Der Geest, K., Ahmed, I., Huq, S. \& Warner, K. A PeopleCentred Perspective on Climate Change, Environmental Stress, and Livelihood Resilience in Bangladesh. Sustainability Science 11, 679-694 (2016).

80. Black, R., Bennett, S. R. G., Thomas, S. M. \& Beddington, J. R. Comment: Migration as Adaptation. Nature 478, 447-449 (2011).

81. Tacoli, C. Not Only Climate Change: Mobility, Vulnerability and Socio-Economic Transformations in Environmentally Fragile Areas of Bolivia, Senegal and Tanzania. Human Settlements Working Paper Series. London: Oversees Development Institute, 2011.

82. Seo, S.N \& R. Mendelsohn. An analysis of crop choice: Adapting to climate change in South American farms. Ecological Economics 67(1), 109-116 (2008).

83. Di Falco, S., Veronesi, M. \& Yesuf, M. Does adaptation to climate change provide food security? A micro-perspective from Ethiopia. American Journal of Agricultural Economics 93(3), 829-846 (2011).

84. Wedawatta G. S. D., Ingirige M. J. B. \& Amaratunga R. D. G. Building up resilience of construction sector SMEs and their supply chains to extreme weather events. International Journal of Strategic Property Management 14(4), 362-375 (2010).

85. International Finance Corporation (IFC) 2004 Annual review small business activities, 2004.

86. Grothmann, T. \& Patt, A. Adaptive capacity and human cognition: the process of individual adaptation to climate change. Glob. Environ. Chang. 15, 199-213 (2005).

87. Hassani-Mahmooei, B. \& Parris, B.W. Climate change and internal migration patterns in Bangladesh: an agent-based model. Environment and Development Economics 17(6), 763-780 (2012).

88. Berkhout, F. Adaptation to climate change by organizations. Wiley Interdisciplinary Reviews: Climate Change 3: 91-106 (2012).

89. Reid, H., \& Huq, S. Community-based adaptation: A vital approach to the threat climate change poses to the poor. International Institute for Environment and Development (IIED). Briefing Paper, London: IIED (2007).

90. Aalst, M. K., Cannon, T. \& Burton, I. Community level adaptation to climate change: The potential role of participatory community risk assessment. Glob. Environ. Chang. 18(1), 165-179 (2008). 
91. Chambers, R. The origins and practice of participatory rural appraisal. World development 22(7), 953-969 (1994).

92. Pathak, S., Pant, L. \& Maharjan A. Depopulation trends, patterns and effects in Uttarakhand, India: A gateway to Kailash Mansarovar. ICIMOD Working Paper 22, Kathmandu: ICIMOD (2017).

93. Gannon, K.E. et al. Business experience of floods and drought-related water and electricity supply disruption in three cities in sub-Saharan Africa during the 2015/2016 El Niño. Global Sustainability 1, e14, 1-15 (2018).

94. Sugden, F. et al. Agrarian stress and climate change in the Eastern Gangetic Plains: Gendered vulnerability in a stratified social formation. Glob. Environ. Chang. 29, 258269 (2014).

95. Piguet, E. Linking climate change, environmental degradation, and migration: a methodological overview. Wiley Interdisciplinary Reviews: Climate Change 1(4), $517-$ 524 (2010).

96. Cooke, B., \& Kothari, U. (Eds.). (2001). Participation: The new tyranny? Zed books.

97. Few, R., Brown, K., \& Tompkins, E. L. Public participation and climate change adaptation: avoiding the illusion of inclusion. Climate policy 7(1), 46-59 (2007).

98. Tschakert, P., Ellis, N. R., Anderson, C., Kelly, A., \& Obeng, J. One thousand ways to experience loss: A systematic analysis of climate-related intangible harm from around the world. Glob. Environ. Chang. 55, 58-72 (2019).

99. Leiter, T., \& Pringle, P. Pitfalls and potential of measuring climate change adaptation through adaptation metrics. In: Christiansen, L., Martinez, G., \& Naswa, P.

(Ed.), Adaptation metrics: Perspectives on comparing, measuring and aggregating adaptation results. Copenhagen, Denmark: UNEP DTU Partnership, (2018).

100. Berrang-Ford, L., Pearce, T., \& Ford, J. D. Systematic review approaches for climate change adaptation research. Reg. Environ. Chang. 15(5), 755-769 (2015).

101. Delaney, A., Chesterman, S., Crane, T.A., Tamás, P.A. \& Ericksen, P. A systematic review of local vulnerability to climate change: In search of transparency, coherence and compatability. CCAFS Working Paper no. 97. CGIAR Research Program on Climate Change, Agriculture and Food Security (CCAFS). Copenhagen, Denmark, 2014.

Available online at: www.ccafs.cgiar.org

102. Kniveton, D., Smith, C. \& Wood, S. Agent-based model simulations of future changes in migration flows for Burkina Faso. Glob. Environ. Chang. 21, S34-S40 (2011).

103. Hassani-Mahmooei, B. \& Parris, B.W. Climate change and internal migration patterns in Bangladesh: an agent-based model. Environment and Development Economics, 17(6), 763-780 (2012).

104. Lobell, D. B., Burke, M. B., Tebaldi, C., Mastrandrea, M. D., Falcon, W. P., \& Naylor, R. L. Prioritizing climate change adaptation needs for food security in 2030. Science, 319(5863), 607-610 (2008).

105. Hazeleger, W., van den Hurk, B.J., Min, E., van Oldenborgh, G.J., Petersen, A.C., Stainforth, D.A., Vasileiadou, E. and Smith, L.A. Tales of future weather. Nature Climate Change, 5(2), 107 (2015).

106. Dessai, S., Bhave, A., Birch, C., Conway, D., Garcia-Carreras, L., Gosling, J.P., Mittal, N. and Stainforth, D.A. Building narratives to characterise uncertainty in regional climate change through expert elicitation. Environmental Research Letters, 13074005 (2018). 
107. McClure, A. Climate narratives What have we tried? what have we learned? What does this mean for us going forward? FRACTAL Briefing note, Future Climate For Africa. Climate Systems Analysis Group, University of Cape Town, 2018. Available from www.fractal.org.za/wp-content/uploads/2018/09/Learning_climate-narrativesbriefing-note.pdf

108. New, M., Bouwer, R. \& Nkemelang, T. Regional changes in climate and its impacts in semi-Arid countries in Africa. ASSAR Working Paper 5: 11pp, 2019. Available from www.assar.uct.ac.za.

109. Vincent, K. and Colenbrander, W. Developing and applying a five step process for mainstreaming climate change into local development plans: A case study from Zambia. Climate Risk Management 21, 26-38 (2018).

110. Miller, C. Hybrid management: boundary organizations, science policy, and environmental governance in the climate regime. Science, Technology, \& Human Values 26(4), 478-500 (2001).

111. Morchain, D., Ziervogel, G., Spear, D., Masundire, H., Angula, M., Davies, J., Hegga, S. \& Molefe C. Building transformative capacity in southern Africa: Surfacing knowledge through participatory Vulnerability and Risk Assessments. Action Research, in press.

112. Totin, E., Butler, J. R., Sidibé, A., Partey, S., Thornton, P. K. \& Tabo, R. Can scenario planning catalyse transformational change? Evaluating a climate change policy case study in Mali. Futures 96, 44-56 (2018).

113. McDermott, T.K.J. \& Surminski, S. How normative interpretations of climate risk assessment affect local decision-making: an exploratory study at the city scale in Cork, Ireland. Phil. Trans. R. Soc. A 376(2121), 20170300 (2018). 


\begin{tabular}{|c|c|c|c|}
\hline & Deltas & $\begin{array}{l}\text { African countries/Semi- } \\
\text { arid lands }\end{array}$ & $\begin{array}{l}\text { River basins dependent on } \\
\text { glaciers and } \\
\text { snowmelt(Indus, Ganges } \\
\text { and Brahmaputra river } \\
\text { basins) }\end{array}$ \\
\hline Top-down & $\begin{array}{l}\text { To assess the cumulative } \\
\text { area in the flood plain, the } \\
\text { magnitude of sea-level rise } \\
\text { in a given year (from }{ }^{43} \text { ) was } \\
\text { added to a modelled surge } \\
\text { component. This was } \\
\text { undertaken for the Ganges- } \\
\text { Brahmaputra, Indian Bengal, } \\
\text { Mahanadi and Volta deltas } \\
\text { in } 2000 \text { and with sea-level } \\
\text { rise at } 1.5^{\circ} \mathrm{C} \text { and } 2.0^{\circ} \mathrm{C} \text { in } \\
2100 \text { and } 2300^{44} \text {. }\end{array}$ & $\begin{array}{l}35 \text { global climate models } \\
\text { (GCMs) were used from } \\
\text { CMIP5 with the RCP } 8.5 \\
\text { forcing scenario for } \\
\text { projections of temperature } \\
\text { and precipitation. They } \\
\text { evaluated the national level } \\
\text { changes in temperature and } \\
\text { precipitation in } 49 \text { African } \\
\text { countries at global warming } \\
\text { levels of } 1.5^{\circ} \mathrm{C} \text { and } 2{ }^{\circ} \mathrm{C}^{45} \text {. }\end{array}$ & $\begin{array}{l}\text { An ensemble of } 2 \text { x } 4 \\
\text { downscaled GCMs } \\
\text { representative of the CMIP5 } \\
\text { ensemble under RCP } 4.5 \text { and } \\
\text { RCP8.5 was used for the } \\
\text { Indus, Ganges and } \\
\text { Brahmaputra river basins in } \\
\text { South Asia. A regional } \\
\text { quantitative assessment of } \\
\text { the impacts of a } 1.5^{\circ} \mathrm{C} \\
\text { versus a } 2^{\circ} \mathrm{C} \text { global warming } \\
\text { was undertaken } 46 .\end{array}$ \\
\hline Bottom-up & $\begin{array}{l}\text { Cross-sectional survey in } \\
120 \text { locations in the Volta, } \\
\text { Mahanadi, Indian Bengal } \\
\text { and Ganges-Brahmaputra- } \\
\text { Meghna (Bangladesh) deltas } \\
\text { that resulted in } 5450 \\
\text { completed questionnaires }^{47} \text {. } \\
\text { Complemented with } \\
\text { observational mixed }^{\text {methods studies }}{ }^{48-51} \text {. }\end{array}$ & $\begin{array}{l}\text { Two examples; } \\
\text { 1.) Data on adaptation } \\
\text { collected through a } \\
\text { structured questionnaire } \\
\text { survey of } 325 \text { small and } \\
\text { medium enterprises in } \\
\text { Kenya and Senegal }{ }^{52} \text {. } \\
\text { 2.) Qualitative interview } \\
\text { methodology used to detail } \\
\text { life histories of individuals } \\
\text { in Ghana, Kenya, Namibia } \\
\text { and India } \\
53 \text {. }\end{array}$ & $\begin{array}{l}\text { A hybrid approach used } \\
\text { employing both qualitative } \\
\text { and quantitative tools in } \\
\text { Chitwan District of the } \\
\text { Gandaki basin in Nepal. } \\
\text { Household surveys using } \\
\text { stratified and some } \\
\text { purposive sampling }{ }^{54} \text {. } \\
\text { Qualitative methods } \\
\text { included focus groups with } \\
\text { communities, and } \\
\text { discussions with local, } \\
\text { district and national level } \\
\text { stakeholders. }{ }^{55} \text {. }\end{array}$ \\
\hline
\end{tabular}

Table 1. Summary of methods used in the studies presented. Full details can be found in the respective publications. 


\begin{tabular}{|c|c|c|c|c|}
\hline \multirow{3}{*}{ Example } & \multicolumn{4}{|c|}{ Global Climate Change } \\
\hline & \multicolumn{2}{|c|}{$1.5^{\circ} \mathrm{C}$} & \multicolumn{2}{|c|}{$2.0^{\circ} \mathrm{C}$} \\
\hline & Projections & Implications & Projections & Implications \\
\hline \multirow[b]{2}{*}{$\begin{array}{l}\text { Deltas } \\
\text { (Ganges- } \\
\text { Brahmaputra } \\
\text { (GB), Indian } \\
\text { Bengal, } \\
\text { Mahanadi and } \\
\text { Volta) } \\
56,57\end{array}$} & \multicolumn{4}{|c|}{ Sea-level rise slows but does not stop with stabilisation, representing a long-term threat. } \\
\hline & $\begin{array}{l}\text { Sea level is projected } \\
\text { to be } 0.40 \mathrm{~m} \text { and } 1.00 \\
\mathrm{~m} \text { above present } \\
\text { values by } 2100 \text { and } \\
2300^{43} \text {, respectively } \\
\text { (plus local } \\
\text { subsidence). }\end{array}$ & $\begin{array}{l}\text { Flood plain area } \\
\text { increases up to } 46 \% \\
\text { (GB); } 80 \% \text { (Indian } \\
\text { Bengal); } 47 \% \\
\text { (Mahanadi); and } \\
58 \% \text { (Volta) from } \\
2000 \text { to } 2100 .\end{array}$ & $\begin{array}{l}\text { Sea level is } \\
\text { projected to be } \\
0.46 \mathrm{~m} \text { and } 1.26 \mathrm{~m} \\
\text { above present } \\
\text { values by } 2100 \text { and } \\
2300^{43}, \\
\text { respectively (plus } \\
\text { local subsidence). }\end{array}$ & $\begin{array}{l}\text { Flood plain area } \\
\text { increases up to } 47 \% \\
\text { (GB); } 80 \% \text { (Indian } \\
\text { Bengal); } 49 \% \\
\text { (Mahanadi); and } 58 \% \\
\text { (Volta) from } 2000 \text { to } \\
2100 .\end{array}$ \\
\hline \multirow[t]{2}{*}{$\begin{array}{l}\text { African } \\
\text { countries/Semi- } \\
\text { arid lands }{ }^{45}\end{array}$} & \multicolumn{4}{|c|}{$\begin{array}{l}\text { The relative change between } 1.5^{\circ} \mathrm{C} \text { and } 2.0^{\circ} \mathrm{C} \text { is much larger for countries with high } \\
\text { aridity. There is greater national level warming relative to global in the more arid } \\
\text { countries, and less warming in more humid countries. African national level temperatures, } \\
\text { and in a number of cases precipitation, are climatologically different at } 1.5^{\circ} \mathrm{C} \text { and } 2.0^{\circ} \text {. } \\
\text { This suggests that at current levels of vulnerability, the differential impacts of climate } \\
\text { change at these two stabilisation levels will be significant. }\end{array}$} \\
\hline & $\begin{array}{l}\text { Of } 49 \text { countries } \\
\text { analysed, only five } \\
\text { show an ensemble } \\
\text { median national } \\
\text { warming less than } \\
1.5^{\circ} \mathrm{C} \text { and } 19 \text { more } \\
\text { than } 1.75^{\circ} \mathrm{C} \text {. } \\
\text { In southern Africa, } \\
\text { all countries show } \\
\text { ensemble median } \\
\text { changes drying; In } \\
\text { East Africa wetting } \\
\text { in all countries, } \\
\text { except Djibouti and } \\
\text { Eritrea. West African } \\
\text { countries exhibit a } \\
\text { mixed signal. }\end{array}$ & $\begin{array}{l}\text { There is a clear } \\
\text { pattern of greater } \\
\text { national level } \\
\text { warming relative to } \\
\text { global in the more } \\
\text { arid countries, and } \\
\text { less warming in } \\
\text { more humid } \\
\text { countries. } \\
\text { The relative change } \\
\text { between } 1.5^{\circ} \mathrm{C} \text { and } \\
2.0^{\circ} \mathrm{C} \text { is much } \\
\text { larger for countries } \\
\text { with high aridity. }\end{array}$ & $\begin{array}{l}31 \text { countries warm } \\
\text { by more than } \\
2.25^{\circ} \mathrm{C} \text { and } 5 \text { by } \\
\text { more than } 2.75^{\circ} \mathrm{C} \text {. } \\
\text { Precipitation } \\
\text { decreases in } \\
\text { southern Africa } \\
\text { become more } \\
\text { severe. In East } \\
\text { Africa the increase } \\
\text { is greater than at } \\
1.5^{\circ} \mathrm{C} \text {. } \\
\text { West African } \\
\text { countries exhibit } \\
\text { similar patterns to } \\
1.5^{\circ} \mathrm{C} \text {. }\end{array}$ & $\begin{array}{l}\text { African national level } \\
\text { temperatures, and in } \\
\text { a number of cases } \\
\text { precipitation, at } \\
1.5^{\circ} \mathrm{C} \text { and } 2.0^{\circ} \text { are } \\
\text { climatologically } \\
\text { different. This } \\
\text { suggests that at } \\
\text { current levels of } \\
\text { vulnerability, the } \\
\text { differential impacts } \\
\text { of climate change at } \\
\text { these two levels will } \\
\text { be significant. }\end{array}$ \\
\hline $\begin{array}{l}\text { River basins } \\
\text { dependent on } \\
\text { glaciers and } \\
\text { snowmelt } \\
\text { (Indus, Ganges } \\
\text { and } \\
\text { Brahmaputra } \\
\text { river basins, } \\
\text { IGB) }\end{array}$ & $\begin{array}{l}\text { A global average } \\
\text { warming of } 1.5^{\circ} \mathrm{C} \text { is } \\
\text { associated with } \\
\text { warming of } 1.4- \\
2.6^{\circ} \mathrm{C} \text { for the IGB. } \\
\text { Precipitation most } \\
\text { likely increases for } \\
\text { the entire IGB. Inter- } \\
\text { annual variability of } \\
\text { precipitation } \\
\text { decreases in areas } \\
\text { with low inter- } \\
\text { annual variability } \\
\text { and increases in } \\
\text { areas with high inter- } \\
\text { annual variability. }\end{array}$ & $\begin{array}{l}\text { Quantitative } \\
\text { changes in a set of } \\
\text { ten climate change } \\
\text { indicators are } \\
\text { linked to expected } \\
\text { impacts for } \\
\text { different sectors. }\end{array}$ & $\begin{array}{l}\text { At } 2.0^{\circ} \mathrm{C} \text { global } \\
\text { average warming, } \\
\text { the IGB is } \\
\text { associated with } 2.0 \\
-3.4^{\circ} \mathrm{C} \text {. } \\
\text { Changes in climate } \\
\text { change indicators } \\
\text { other than air } \\
\text { temperature } \\
\text { correlate linearly } \\
\text { with temperature } \\
\text { increase. } \\
\text { The range in the } \\
\text { precipitation } \\
\text { projections is } \\
\text { large. }\end{array}$ & $\begin{array}{l}\text { The regional impacts } \\
\text { of climate change } \\
\text { will be more severe } \\
\text { for } 2.0^{\circ} \mathrm{C} \text { than } 1.5^{\circ} \mathrm{C} \text {. } \\
\text { Temperature } \\
\text { differences can be } \\
\text { largely attributed to } \\
\text { elevation-dependent } \\
\text { warming in the } \\
\text { upstream IGB basins, } \\
\text { i.e. the stronger } \\
\text { warming of areas at } \\
\text { high altitude } \\
\text { compared to low- } \\
\text { lying areas. }\end{array}$ \\
\hline
\end{tabular}

Table 2. Summary of three studies in climate sensitive systems focussing on climate model projections and implications at $1.5^{\circ} \mathrm{C}$ and $2.0^{\circ} \mathrm{C}$. GB is Ganges and Brahmaputra delta. 